\title{
DROSHA Gene Mutation
}

National Cancer Institute

\section{Source}

National Cancer Institute. DROSHA Gene Mutation. NCI Thesaurus. Code C158669.

A change in the nucleotide sequence of the DROSHA gene. 